\title{
Morphological and molecular characterization of Fusarium verticillioides (F. moniliforme) associated with Post-Flowering Stalk Rot (PFSR) of Maize in Karnataka
}

\author{
S. Dharanendra Swamy ${ }^{1}$, S. Mahadevakumar ${ }^{1}$, H.B. Hemareddy ${ }^{2}$, K.N. Amruthesh ${ }^{1}$, S. Mamatha ${ }^{2}$, G. Sridhara \\ Kunjeti $^{3}$, K. R. Sridhar ${ }^{4}$, R. Swapnil ${ }^{2}$, T. Vasantha Kumar ${ }^{5}$ and N. Lakshmidevi ${ }^{6}$ \\ ${ }^{\prime}$ Department of Studies in Botany, Manasagangotri, University of Mysore, Mysuru-570 006, Karnataka, India \\ ${ }^{2}$ Bayer Crop Science Ltd., Kallinayakanahalli, Thondebhavi Post - 561213, Gauribidanur Taluk, Chikkaballapura District, \\ Karnataka, India. \\ ${ }^{3}$ Monsanto Holdings Pvt. Ltd. (a subsidiary of Bayer AG), Kallinayakanahalli, Thondebhavi Post - 561213, Gauribidanur Taluk, \\ Chikkaballapura District, Karnataka, India \\ ${ }^{4}$ Department of Biosciences, Mangalore University, Mangalagangotri, Mangalore 574 199, Karnataka, India. \\ ${ }^{5}$ Green Life Science Technologies, \#765, $8^{\text {th }}$ main, B Block, $3^{\text {rd }}$ stage, Vijayanagara, Mysuru-570 030, Karnataka, India. \\ ${ }^{6}$ Department of Studies in Microbiology, Manasagangotri, University of Mysore, Mysuru-570 006, Karnataka, India. \\ *Corresponding author Email:lakshmiavina@rediffmail.com
}

(Submitted on November 5, 2019; Accepted on December 17, 2019)

\section{ABSTRACT:}

\begin{abstract}
Maize (Zea mays L.) is the major staple cereal crop in the world and is the third-largest grown cereal crop in India. Field surveys conducted from 2013-15 recorded stalk rot incidence ranged from 18-45\% in 10 major maize growing districts of Karnataka state. The typical symptoms were observed after flowering season and it starts with the drying of the lower leaves and premature wilting, lower internodes turned into grey-green color and stalks are hollow and weak leading to the lodging of the plant. In our previous studies, we identified several pathogens associated with stalk rot disease incidence and Fusarium turned out to be major threat in all the study regions. However, identity of the Fusarium isolate was not confirmed. Therefore, in the present study, identification was confirmed as Fusarium verticillioides by morphological, cultural and molecular sequence analysis was done. Fusarium species associated with stalk rot disease were isolated on the PDA medium. A total of 219 fungal isolates were obtained from Post Flowering Stalk Rot samples and 132 were identified as $F$. verticillioides which represented more than $68 \%$ of total isolations. Isolates were identified based on cultural and morphological characteristics. However, identity of 12 selected isolates was confirmed by molecular identification. The ITS-rDNA and TEF gene were amplified and sequenced using ITS1/ITS4, TEF1/TEF2 primer pairs, respectively. The BLASTn search and phylogenetic analysis confirmed their identity as Fusarium verticillioides. Pathogenicity tests conducted on 60-day-old maize plants by injecting conidial suspension produced typical stalk rot symptoms after 30 days of post-inoculation and the pathogen's identity was re-confirmed by cultural and morphological features. Occurrence of $F$. verticillioides with ear rot, seed borne incidence and root rot of maize was reported from different regions. However, association of $F$. verticillioides and its molecular characterization by ITSrDNA and TEF from Karnataka were limited and the present study provided evidence for the occurrence of $F$. verticillioides as a major disease causing pathogen of stalk rot.
\end{abstract}

KEYWORDS: Relative per cent occurrence, Disease severity score, Post-flowering stalk rot, pathogenicity, molecular identification.

\section{INTRODUCTION}

Maize (Zea mays L.) is one of the most significant food crops with the worldwide region under maize cultivation is roughly 183 Mha with a production of 1065 MT and productivity of 5.82 tons/ha during 2013-14 (Kling and Edmeades, 1997; Anon., 2016; Swamy et al., 2019).The United States and China are the leading producers of the maize followed by Brazil, Argentina, and India. In India, maize is the third most important cereal crop after rice and wheat, accounting for $\sim 9$ $\%$ of total food grain production. It was cultivated in an area of 9.6Mha during 2016-17 with a productivity of 2.71 tonnes/ha (Anon, 2017). Karnataka, Andhra Pradesh, Bihar, Madhya Pradesh, Rajasthan, Maharashtra, Tamil Nadu, Uttar Pradesh and Chhattisgarh are the major maize growing states in India.

Stalk rot disease of maize is one among the major disease throughout the world (Christensen and Wilcoxson, 1966; De Leon and Pandey, 1989). This disease is caused by a complex of pathogens (bacteria and fungi) and secondary colonizers. Further, fungi associated with stalk rot vary from region to region and cause significant economic damage to the productivity. Fusarium verticillioides is the major cause of the fungal stalk rot disease of maize. The other important species of Fusarium known to cause stalk rot across regions were $F$. graminearum, F. temperatum, $F$. subglutinans and $F$. proliferatum (Marasas et al., 1984; Afolabi et al., 2008; Gilbertson et al., 1985; White, 1999). However, there are no clear reports on the occurrence of post flowering stalk rot (PFSR) of maize caused by $F$. verticillioides and their morpho-cultural and molecular characterization from Karnataka. The present study was conducted in major maize growing districts of Karnataka with the aim at estimating PFSR disease and the characterization of associated fungal pathogens through morphological, cultural and molecular characterization (ITS-rDNA and Translation Elongation Factor gene). Further, pathogenicity tests were performed for selected PFSR isolates and disease severity score was recorded.

\section{MATERIALAND METHODS}

Sampling locations: Field surveys were conducted in major maize growing districts of Karnataka (Belgaum, Bagalkot, Davanagere, Haveri, Chitradurga, Bellary, Koppala, Gadag, Dharwad and Chikkaballapur) during Kharif season of 2013 2015.This study recorded the occurrence of maize stalk rot disease on matured plants from all the above 10 districts. Characteristic disease symptoms were observed and recorded. A total of 2009 fields were evaluated between the 
study period and sampling was made randomly. PFSR samples were collected and brought to the laboratory for isolation of associated pathogens.

Isolation and identification of the pathogen: A total of 622 PFSR affected samples were collected and brought to the laboratory for isolation of associated fungal pathogen and further used for morphological, cultural and molecular identification of the associated pathogen. Briefly, PFSR affected stem regions were cut into small pieces $(0.5 \mathrm{~cm})$, surface-sterilized with $2 \%$ sodium hypochlorite solution (v/v) for 3 min., washed thrice in sterile water, blotter dried and then plated on to potato dextrose agar (PDA) medium (HiMedia Laboratories, Mumbai) amended with Chloramphenicol $(40 \mathrm{mg} / \mathrm{L})$ into Petri dishes, and incubated at room temperature $\left(28 \pm 2^{\circ} \mathrm{C}\right)$ (Mahadevakumar et al., 2017). Fungal colonies displaying morphological characteristics of Fusarium species were sub-cultured by picking mycelial plough (disc) and inoculated on to PDA to obtain pure cultures and were subjected for morphological and molecular identification. Morphological identification was performed by studying the nature of colony, macro conidia, micro conidia and chlamydospores produced after 7-10 days of incubation at room temperature (Booth, 1971; Leslie and Summerell, 2006). Relative per cent occurrence (RPO) of $F$. verticillioides and other fungal species associated with PFSR were calculated by using the formula (Deepa et al., 2016b);

\footnotetext{
Relative per cent occurrence $=\stackrel{\text { No. of PFSR sample with Fverticilloides }}{-} \times 100$

Total number of PFSR samples used for isolation
}

Molecular identification: The genomic DNA was isolated from 10 days old cultures of the pathogen using CTAB method (Zhang et al., 1998; Mahadevakumar et al., 2018, 2019). The PCR reaction was carried out with Eppendorf Master Gradient Thermocycler (Eppendorf, Germany) by employing the ITS1-ITS4 (White et al., 1990) and TEF1/TEF2 (O'Donnel et al., 1998; Geiser et al., 2004) primer pairs for amplification of Internal Transcribed Spacer region of ribosomal DNA (ITS-rDNA) and translation elongation factor (TEF) genes, respectively. The PCR amplification was carried out in $25 \mu \mathrm{L}$ reaction mixture containing $1 \mu \mathrm{L}$ of DNA sample, $12.5 \mu \mathrm{L}$ of ready-mix (SIGMA Aldrich, USA), $20 \mathrm{pM}$ of each forward and reverse primers $(1.0 \mu \mathrm{L})$ (Genie, Bangalore, India) and the final volume was made up to $25 \mu \mathrm{L}$ with $9.5 \mu \mathrm{L}$ of nuclease-free water. The PCR conditions include initial denaturation at $95^{\circ} \mathrm{C}$ for $3 \mathrm{~min}$., followed by 35 cycles of denaturation at $94^{\circ} \mathrm{C}$ for $40 \mathrm{~s}$., primer annealing $30 \mathrm{~s}$ at $53^{\circ} \mathrm{C}$ for ITS, $56^{\circ} \mathrm{C}$ for TEF, followed by extension at $72^{\circ} \mathrm{C}$ for $1 \mathrm{~min}$, and a final extension at $72^{\circ} \mathrm{C}$ for $10 \mathrm{~min}$. The amplified PCR products were sequenced using an ABI3730xI DNA analyzer (Applied Biosystems, Foster City, CA, USA). Representative reference sequences were retrieved from the NCBI-GenBank database. For sequence analysis nucleotide BLAST (BLASTn) search was performed using each DNA sequences with Fusarium spp. Later, a phylogenetic analysis was performed with the sequences of several Fusarium spp. retrieved from GenBank. Sequences were aligned using CLUSTAL-W program and
MEGA 7.0 was used to construct Maximum Likelihood phylogenetic trees with Nucleotide substitute-Tamura-Nei model with 1000 bootstrap replications for individual and combined phylogenetic tree (Tamura et al., 2004, 2013).

Pathogenicity test: To determine the pathogenicity, Koch's postulates were performed using 12 representative isolates of PFSR samples by inoculating the conidial suspension ( $2 \mathrm{~mL} /$ plant)of the isolated fungal pathogen by using a sterile syringe $\left(2 \times 10^{6}\right.$ conidia $\left./ \mathrm{mL}\right)$ at second internode from the base of the plant on 30 healthy maize plants per isolate (60 days old) in triplicates (Rakesh et al., 2016). The control plants were inoculated (injected) with sterile distilled water. The experiment was conducted in three replicates and repeated thrice. Post-inoculation, the development of the stalk rot disease was recorded after 30 days of inoculation. Disease severity was measured using 1-9 scale (Shekhar and Kumar, 2012) in which Scale 1 - Healthy or slight discoloration at the site of inoculation; Scale 2 - Up to $50 \%$ of the inoculated internode is discolored; Scale $3-51-75 \%$ of the inoculated internode is discolored; Scale $4-76-100 \%$ of the inoculated internode is discolored; Scale 5 - Less than 50\% discoloration of the adjacent internode; Scale 6 - More than 50\% discoloration of the adjacent internode; Scale 7 Discoloration of three internodes; Scale 8 - Discoloration of four internodes; Scale 9 - Discoloration of five or more internodes and premature death of plant. The pathogen was re-isolated to confirm its identity through morphological and cultural characteristics.

\section{RESULTS}

In the present study, survey conducted in major maize growing regions showed the severe occurrence of stalk rot disease. The stalk rot infected maize plants showed symptoms which included premature drying of lower leaves resulting in wilting or drying of the entire plant as the disease progressed. Infected stalks were green initially and later turned to gray colour and lost its firmness. The pith gets dissolved as a result, the stalk lost its strength and such stalks were lodged when there was a wind or when the harvest was delayed (Fig. 1). When we split open the stalks affected with stalk rot, light brown discoloration of the pith and sometimes pink color pigmentation was observed. Lodging was observed in severely affected plants. Infection of stalk was observed up to

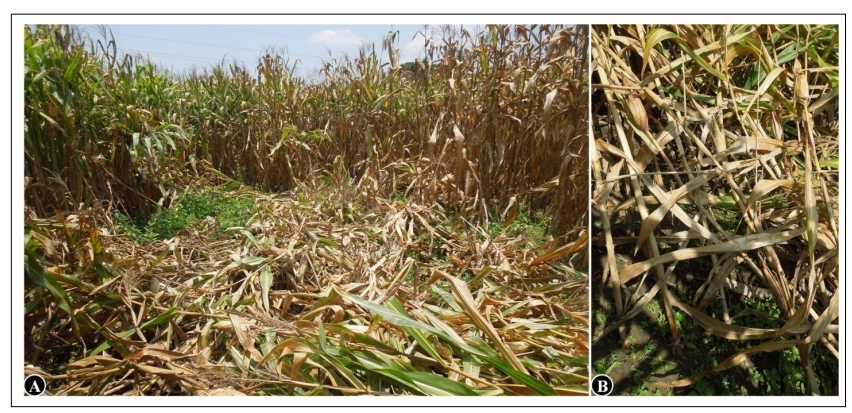

Fig. 1. Typical symptoms of PFSR of maize observed in Karnataka: A. PFSR cased lodging of maize plants B. Enlarge view of maize stalk showing lodging due to PFSR infection. 


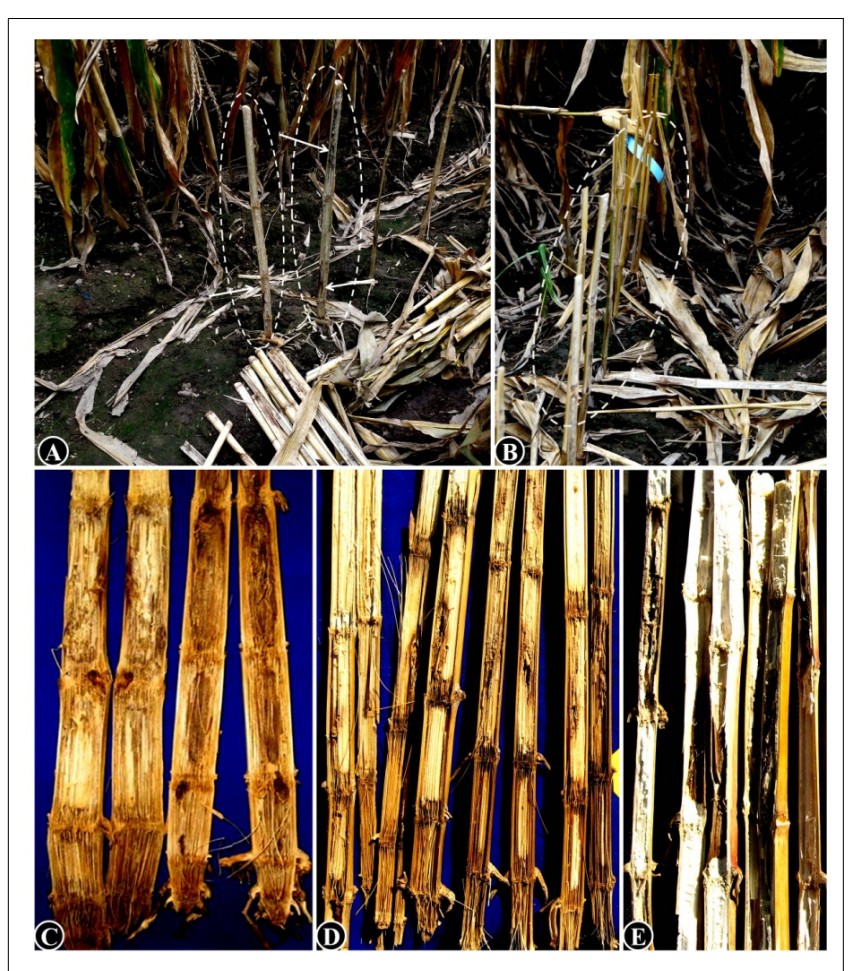

Fig. 2. Close view of PFSR affected maize stalks caused by Fusarium verticillioides observed in Karnataka.

3-internodal regions from the stem to soil interface (Fig. 2).

We reported the prevalence and incidence of PFSR from the study regions (Swamy et al., 2019) and occurrence of Fusarium species, but information was deficient on species of Fusarium associated with PFSR and its pathogenic behavior upon challenge inoculation. Associated fungal pathogens were identified only up to the genus (i.e. Fusarium) and no species limitations were reported. In continuation of our investigation, we found that PFSR of maize was severely affected by $F$. verticillioides.

Among 622 PFSR samples screened for the isolation of associated fungal pathogens, a total of 219 isolates were obtained of which132 isolates were of Fusarium verticillioides $(60.27 \%)$ across the study regions. However, a total of 87 isolates were recovered as the other fungal species (OFS) associated with the PFSR samples. Out of 87 isolates, 19 isolates were of $F$. equiseti $(8.67 \%), 32$ isolates were of other Fusarium species (14.61\% unidentified), 18 isolates were of Macrophomina phaseolina (8.21\%), 12 isolates were of Lasiodiplodea theobromae (5.47\%), and 6 isolates were of L. pseudotheobromae (Authors personal communication). Identification of these OFS isolates was made based on morphology and cultural characteristics (data not provided). The number of PFSR samples collected from each district and the number of samples with $F$. verticillioides infection and with OFS were recorded and presented in Fig. 3. A total 291 PFSR samples were screened in 2013, out of which 200 samples were found associated with $F$. verticillioides across the regions. Similarly, in 2014 and 2015, a total of 161 and 170 PFSR samples were screened and 105 and 121 samples were found infected with $F$. verticillioides, respectively. Combining all three years data, a total of 622 PFSR samples were analyzed and 426 PFSR samples were found associated with $F$. verticillioides with relative per cent occurrence of $68.36 \%(\mathrm{FV})$ and $31.64 \%$ for OFS (Fig. 4).

The fungal colony on PDA were initially white, floccose which turned to dark brown after 7 days of incubation at $28 \pm 2^{\circ} \mathrm{C}$. Cultures developed pigmentation like pink, light purple, dark violet which varied with age (Fig. 5).

Microconidia were oval to club shaped with a flattened base and measured $3.32-12.43 \times 1.03-4.94 \mu \mathrm{m}(\mathrm{L} \times \mathrm{W})$. They were formed from monophialides and were found in long chains (Fig. 6A-D). Chlamydospores are not produced, except for the appearance of pseudochlamydospore like structures due to hyphal modifications. Macroconidia production was observed rarely and in isolates where the macroconidia observed with apical cell curved and tapered, and basal cell notched. They were typically $4-6$ celled with 35 septa and measured $24.73-35.94 \times 4.61-7.22 \mu \mathrm{m}(\mathrm{L} \times \mathrm{W})$. Macroconidia were obscured by abundant microconidial chains (Fig. 6E-G). A total of 132 isolates were identified as Fusarium verticillioides in the present study. Further, 12

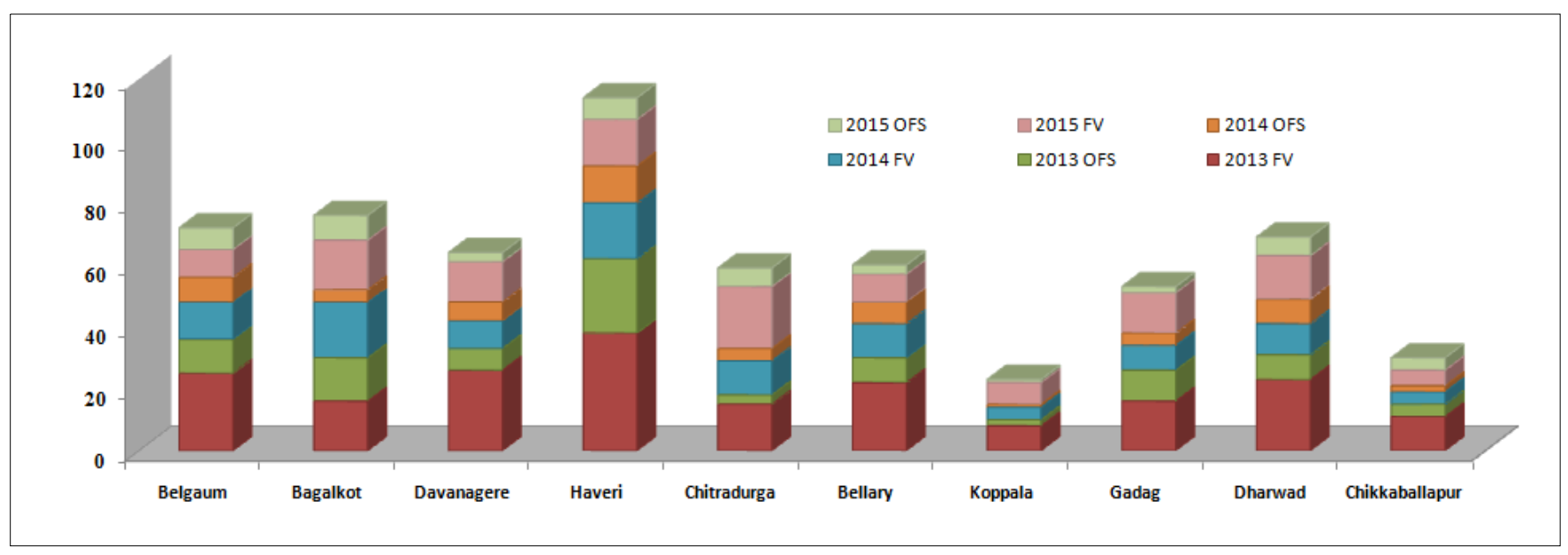

Fig. 3. Number of PFSR samples infected by F. verticillioides (FV) and Other Fungal Species (OFS) recorded from each district 


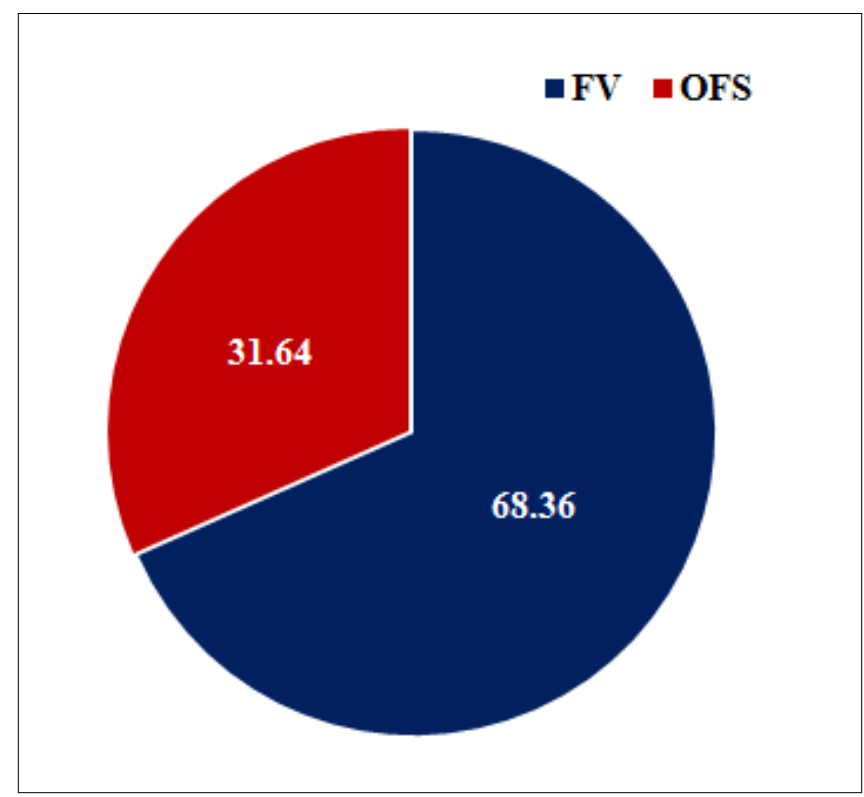

Fig.4. Relative percent occurrence of Fusarium verticillioides and other fungal species associated with PFSR recorded from Karnataka during 2013-15.
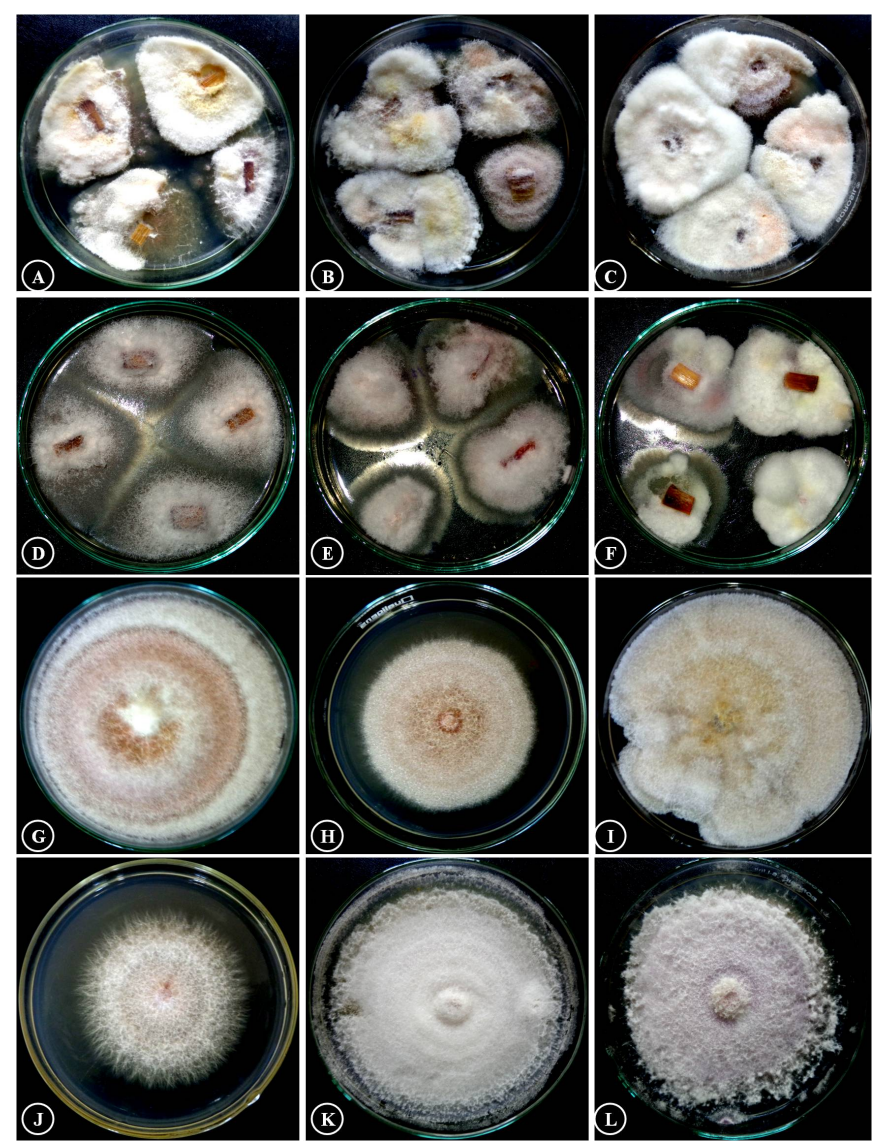

Fig. 5. Cultural characteristics of Fusarium verticillioides isolated from PFSR of maize samples: A-F Fungal colony developed directly from the inoculated PFSR sample on PDA medium after 7 days of incubation; $\mathbf{G}$ - L Pure cultures of $F$. verticillioides (monoconidial isolation) on PDA medium after 10 days of incubation.

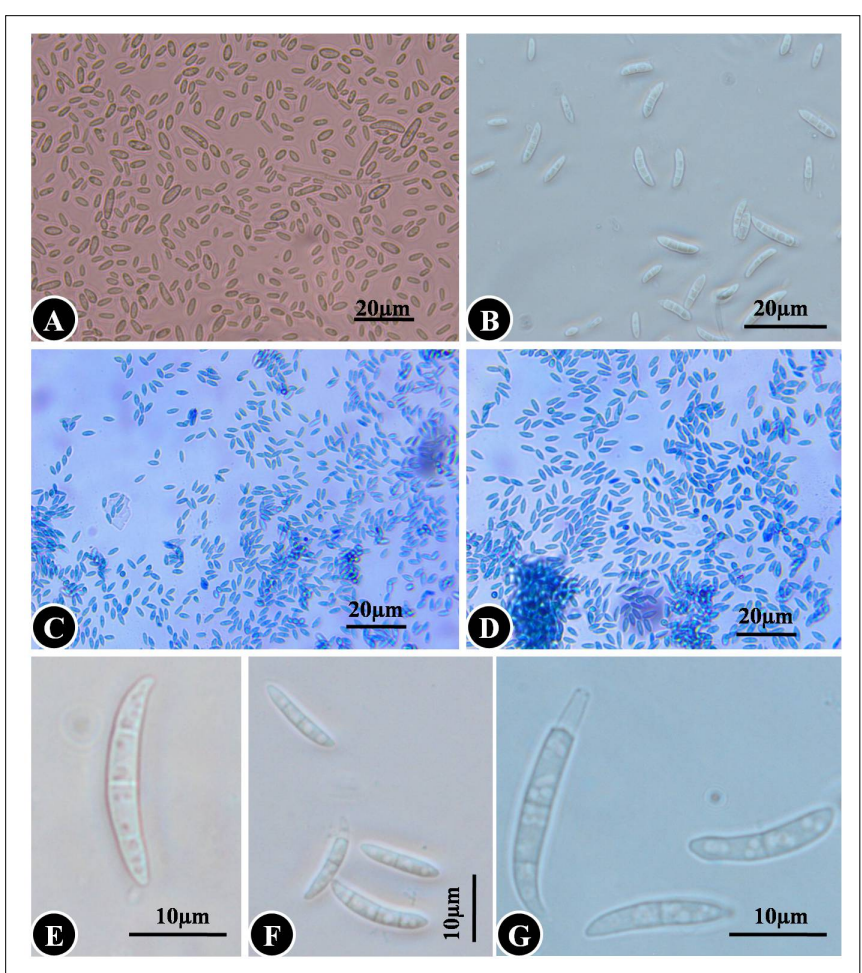

Fig. 6. Micro morphology of Fusarium verticillioides associated with PFSR of maize samples A-B Microconidia of $F$. verticillioides observed under compound microscope; C-D Micro and macro Conidia of $F$. verticillioides; E-G Macro conidia observed under compound microscope.

representative isolates representing each district with exception of Haveri and Dharwad districts which included 2 representative isolates taken for validation with molecular sequence analysis of ITS-rDNA and EF1 gene. Therefore, morphological features (cultural features, microconidia and macroconidia) of the selected 12 isolates are presented in Table 1.

Representative isolates of $F$. verticillioides were selected and subjected for molecular identification for amplification of ITS-rDNA and TEF- $1 \alpha$ genes. The expected PCR amplicons were amplified for ITS-rDNA and TEF gene using ITS1-ITS4 universal primers, and TEF1-TEF2 primers and were purified, sequenced. The ITS-rDNA sequence showed 99$100 \%$ similarity with references of $F$. verticillioides in GenBank database. TEF sequences of the isolates against Fusarium multi-locus sequence typing (MLST) database showed 99 to $100 \%$ similarity with Fusarium verticillioides. Later, consensus sequences of ITS and TEF regions of all isolates were analyzed in nBLAST, and results showed 99\% similarity with reference sequences from GenBank database. The GenBank accession numbers (ITS-rDNA and EF1) of these 12 representative isolates of $F$. verticillioides were presented in Table 1. Based on morphological features, cultural characteristics and molecular sequence data, the selected representative PFSR isolates were identified as Fusarium verticillioides (Sacc.) Nirenberg (Sexual morph: Gibberella moniliformis) (Booth 1971; Leslie and Summerell 2006; Li et al., 2017). 
Table 1. Morphological features of Fusarium verticillioides isolates associated with PFSR of maize in Karnataka and their pathogenicity and disease severity score.

\begin{tabular}{|c|c|c|c|c|c|c|}
\hline PFSR isolate & Location & $\begin{array}{c}\text { Culture on } \\
\text { PDA }\end{array}$ & Macroconidia & $\begin{array}{c}\text { Micro- } \\
\text { conidia }\end{array}$ & $\begin{array}{l}\text { \#GB Acc. No. } \\
\text { (ITS \& EF1) }\end{array}$ & $\underset{*}{\text { Pathogenicity }}$ \\
\hline PFSR_Fv18 & Belgaum & $\begin{array}{l}\text { White, later } \\
\text { turned pink }\end{array}$ & $\begin{array}{l}\text { Macroconidia } \\
\text { were very few } \\
\text { and 3-5 septate; } \\
27.17-35.68 \times \\
4.61-6.94 \mu \mathrm{m}\end{array}$ & $\begin{array}{l}4.21-11.22 \\
\times 1.31-3.59 \\
\mu \mathrm{m}\end{array}$ & $\begin{array}{c}\text { MN652641.1 \& } \\
\text { MN657266.1 }\end{array}$ & $\begin{array}{l}\text { Pathogenic } \\
\text { DS:5 }\end{array}$ \\
\hline PFSR_Fv27 & Bagalkot & $\begin{array}{l}\text { Initially white, } \\
\text { later turned } \\
\text { Purple violet }\end{array}$ & Not Observed & $\begin{array}{c}5.11-10.8 \times \\
1.03-3.25 \\
\mu \mathrm{m}\end{array}$ & $\begin{array}{c}\text { MN652642.1 \& } \\
\text { MN657267.1 }\end{array}$ & $\begin{array}{c}\text { Pathogenic } \\
\text { DS:7 }\end{array}$ \\
\hline PFSR_Fv39 & Davanagere & $\begin{array}{l}\text { Initially white, } \\
\text { then turned } \\
\text { Light Pink }\end{array}$ & $\begin{array}{c}\text { Macroconidia } \\
\text { were } 4-5 \\
\text { septate, } 24.73- \\
32.62 \times 4.13- \\
5.97 \mu \mathrm{m} .\end{array}$ & $\begin{array}{c}5.08-9.28 \times \\
1.32-3.94 \\
\mu \mathrm{m}\end{array}$ & $\begin{array}{c}\text { MN652643.1 \& } \\
\text { MN657268.1 }\end{array}$ & $\begin{array}{c}\text { Pathogenic } \\
\text { DS: } 7\end{array}$ \\
\hline PFSR_Fv42 & Haveri & $\begin{array}{l}\text { Initially white, } \\
\text { later turned } \\
\text { Purple violet }\end{array}$ & Not Observed & $\begin{array}{c}4.18-10.08 \\
\times 1.08-3.29 \\
\mu \mathrm{m}\end{array}$ & $\begin{array}{c}\text { MN652644.1 \& } \\
\text { MN657269.1 }\end{array}$ & $\begin{array}{c}\text { Pathogenic } \\
\text { DS:5 }\end{array}$ \\
\hline PFSR_Fv58 & Haveri & $\begin{array}{l}\text { Initially white, } \\
\text { later turned } \\
\text { Pink color }\end{array}$ & Not Observed & $\begin{array}{c}4.52-11.84 \\
\times 1.24-3.11 \\
\mu \mathrm{m}\end{array}$ & $\begin{array}{c}\text { MN652645.1 } \\
\& \\
\text { MN657270.1 }\end{array}$ & $\begin{array}{c}\text { Pathogenic } \\
\text { DS:7 }\end{array}$ \\
\hline PFSR_Fv70 & Chitradurga & $\begin{array}{c}\text { Initially white, } \\
\text { later turned } \\
\text { Light Pink } \\
\text { with age }\end{array}$ & Not Observed & $\begin{array}{c}6.57-12.43 \\
\times 2.13-2.98 \\
\mu \mathrm{m}\end{array}$ & $\begin{array}{c}\text { MN652646.1 } \\
\& \\
\text { MN657271.1 }\end{array}$ & $\begin{array}{c}\text { Pathogenic } \\
\text { DS:6 }\end{array}$ \\
\hline PFSR_Fv77 & Bellary & $\begin{array}{l}\text { Initially white, } \\
\text { later turned } \\
\text { Purple violet }\end{array}$ & $\begin{array}{c}\text { Macroconidia } \\
\text { were } 3-4 \text { septate } \\
35.71-40.56 \times \\
4.87-7.12 \mu \mathrm{m} .\end{array}$ & $\begin{array}{c}5.65-10.86 \\
\times 1.55-2.94 \\
\mu \mathrm{m}\end{array}$ & $\begin{array}{c}\text { MN652647.1 } \\
\& \\
\text { MN657272.1 }\end{array}$ & $\begin{array}{c}\text { Pathogenic } \\
\text { DS:7 }\end{array}$ \\
\hline PFSR_Fv81 & Bellary & $\begin{array}{l}\text { Initially white, } \\
\text { later turned } \\
\text { Pink color }\end{array}$ & $\begin{array}{c}\text { Macroconidia } \\
\text { were 2-3 septate } \\
27.17-35.94 \times \\
4.69-7.22 \mu \mathrm{m} .\end{array}$ & $\begin{array}{c}3.32-8.13 \times \\
1.92-3.58 \\
\mu \mathrm{m}\end{array}$ & $\begin{array}{c}\text { MN652648.1 } \\
\& \\
\text { MN657273.1 }\end{array}$ & $\begin{array}{c}\text { Pathogenic } \\
\text { DS:6 }\end{array}$ \\
\hline PFSR_Fv88 & Koppala & $\begin{array}{c}\text { Initially white, } \\
\text { later turned } \\
\text { Purple violet }\end{array}$ & Not Observed & $\begin{array}{c}5.36-12.27 \\
\times 2.42-4.25 \\
\mu \mathrm{m}\end{array}$ & $\begin{array}{c}\text { MN652649.1 } \\
\& \\
\text { MN657274.1 } \\
\end{array}$ & $\begin{array}{c}\text { Pathogenic } \\
\text { DS:8 }\end{array}$ \\
\hline PFSR_Fv93 & Gadag & $\begin{array}{c}\text { Initially white } \\
\text { and later } \\
\text { turned Pink }\end{array}$ & Not Observed & $\begin{array}{c}4.27-10.22 \\
\times 2.38-4.49 \\
\mu \mathrm{m}\end{array}$ & $\begin{array}{c}\text { MN652650.1 } \\
\& \text { MN657275.1 }\end{array}$ & $\begin{array}{c}\text { Pathogenic } \\
\text { DS:7 }\end{array}$ \\
\hline PFSR_Fv102 & Dharwad & $\begin{array}{l}\text { Initially white, } \\
\text { later turned } \\
\text { Light Pink }\end{array}$ & Not Observed & $\begin{array}{c}5.58-10.25 \\
\times 2.28-4.94 \\
\mu \mathrm{m}\end{array}$ & $\begin{array}{c}\text { MN652651.1 } \\
\& \\
\text { MN657276.1 } \\
\end{array}$ & $\begin{array}{l}\text { Pathogenic } \\
\text { DS:6 }\end{array}$ \\
\hline PFSR_Fv118 & $\begin{array}{c}\text { Chikkaballap } \\
\text { ur }\end{array}$ & $\begin{array}{c}\text { Initially white, } \\
\text { later turned } \\
\text { Purple }\end{array}$ & Not Observed & $\begin{array}{c}4.98- \\
10.508 \times \\
1.43-3.95 \\
\mu \mathrm{m}\end{array}$ & $\begin{array}{c}\text { MN652652.1 } \\
\& \\
\text { MN657277.1 }\end{array}$ & $\begin{array}{l}\text { Pathogenic } \\
\text { DS:8 }\end{array}$ \\
\hline
\end{tabular}

The evolutionary history was inferred using the NeighborJoining method (Saitou and Nei, 1987). The percentage of replicate trees in which the associated taxa clustered together in the bootstrap test (1000 replicates) is shown next to the branches (Felsenstein, 1985). The evolutionary distances were computed using the Maximum Composite Likelihood method (Tamura et al., 2004) and are in the units of the number of base substitutions per site. The analysis involved 33 nucleotide sequences. There were a total of 503 positions in the final dataset and all positions containing gap and missing data were eliminated. Evolutionary analyses were conducted in MEGA7.0 (Kumar et al., 2016). The phylogenetic analysis of ITS and TEF gene revealed that the fungal isolates from the present study shared a common clade 


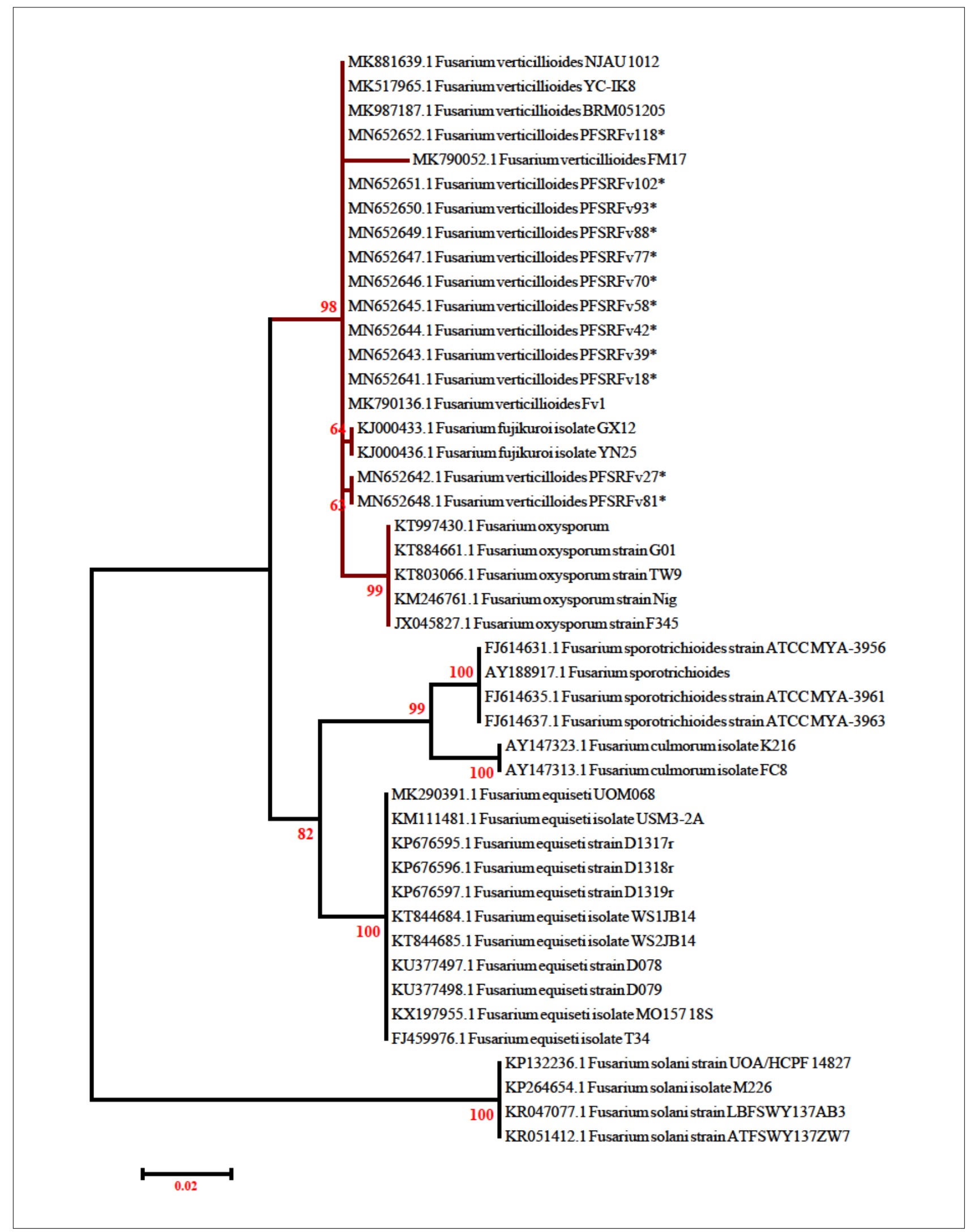

Fig.7. Phylogenetic tree constructed by Maximum Likelihood method inferred from ITS-rDNA sequences showing relationships among isolates of Fusarium verticillioides and related Fusarium species (Substitution nucleotide Tamura-Nei model and boot strap methods with 1000 bootstrap replications). 
(Fig. 7\&8) with $F$. verticillioides represented by reference sequences retrieved from GenBank and combined ITS and TEF phylogenetic tree (Fig. 9) analysis also showed similar results thereby confirming the identity as $F$. verticillioides based on morphological, cultural and molecular sequence analysis. Based on the micro-morphological, cultural characteristics and molecular sequence analysis, the fungal isolates were identified as $F$. verticillioides.

The pathogenicity tests conducted for all 12 selected isolates by inoculating the second internode of maize through conidial suspension produced typical stalk rot symptoms. The typical PFSR symptoms were observed in challenge inoculated plants were drying of the lower leaves, lower internodes turned into grey-green color and wilt of entire plant prematurely, and stalks are hollow and weak leading to the lodging of the plant. No such symptoms were observed in controls. All the tested isolates were pathogenic on tested maize cultivar (cv. Nithyashree). However, the disease severity was varied among the isolates. PFSR isolates PFSRFv_88 and PFSRFv_118 were highly virulent which caused severe infection upon challenge inoculation with disease score 8 (discoloration of four internodes) followed by PFSRFV 27, 39, 58,77 and 93 isolates were virulent and caused severe infection with disease score 7 (discoloration of three internodes). The results of pathogenicity test and disease severity score for each isolate is presented in Table 1. The fungal isolates after challenge inoculation and upon development of characteristic symptoms were consistently re-isolated and their identity was confirmed. Koch's postulates were fulfilled thus confirming the association of $F$. verticillioides with PFSR of Maize.

\section{DISCUSSION}

Fusarium verticillioides is an important pathogen causing diseases in maize (stalk rot, ear rot and kernel rot) and many other crops worldwide (Bacon and Nelson, 1994; Gai et al., 2018). It produces fumonisins that accumulates in the kernels making them toxic to animals and humans and associated with animal disease syndromes. The stalk rot of maize was first reported from the United States of America by Pammel (1914) as a serious root and stalk diseases caused by $F$. verticillioides leads to significant yield losses across the globe and also impacts the health of humans and animals (Marasas, 2001; Shim et al., 2003; Rheeder et al., 2002). The PFSR is reported for the first time in India by Arya and Jain (1964) from Rajasthan. The PFSR is one of the most destructive diseases in maize growing countries which significantly affect the production (Shan et al., 2017). The present research set out with the point of distinguishing Fusarium species associated with PFSR of maize from major maize growing districts of Karnataka. This report confirms the PFSR as a major problem across the maize growing regions.

In India, however, there are severe constraints in the production of maize from various fungal diseases including stalk rot which is a major threat in terms of crop loss and quality of seed production. The PFSR is a complex caused by various species of Fusarium and other pathogenic fungi, like M. phaseolina, Botryodiplodia theobromae and others.
Among species of Fusarium, F. verticillioides was the major cause and there were several species which includes $F$. subglutinans ( $F$. semitectum), F. avenaceum, $F$. sulphurcum, $F$. acuminatum, $F$. roseum, $F$. merismoides, $F$. nivale and $F$. solani which were reported to cause stalk rot of maize (Dorn et al., 2009; Kommedahal et al., 1972, Nur-Ain-Izzati et al., 2011; Orsi et al., 2000). Association of $F$. equiseti with sheath rot of maize was reported from China (Li et al. 2014). In India, association of $F$. equiseti with Post flowering stalk rot of maize was reported by Swamy et al. (2020). Earlier, F. moniliforme ( $F$. verticillioides) and $F$. semitectum are the only two Fusarium species known to cause PFSR (Khokhar et al., $2013,2014)$ in India. But, there is no detailed information on the occurrence of PFSR in Karnataka and the causal agent. Therefore, a detailed survey was conducted in major maize growing regions during 2013-15 and occurrence of Fusarium species was observed in more than $60 \%$ of samples analyzed (Swamy et al., 2019). However, no specific information was given on Fusarium species associated with PFSR in Karnataka. The present paper reports more than $68 \%$ of the PFSR samples which were found affected with $F$. verticillioides and $32 \%$ with OFS which includes Macrophomina phaseolina, F. equiseti, Lasiodiplodea theobromae, and L. pseudotheobromae.

Association of $F$. verticillioides causing stalk rot was previously reported from Rajasthan and other major maize growing states (Borah et al. (2016; Jat et al., 2017). Seed borne nature and transmission of $B$. theobromae on maize was reported by Vasanthkumar and Shetty (1983) which caused stalk rot in India. In Karnataka, occurrence of $F$. verticillioides from grains, ears of maize and the production of fumonisin were reported by various workers (Deepa et al., 2016, 2018; Nagaraja et al., 2016). Seed borne occurrence of $F$. verticillioides was also reported from Karnataka by Nayaka $e t$ al. (2008), but morphological and molecular characterization of $F$. verticillioides associated with PFSR was not available. The present study provided identification based on morphology, and molecular sequence analysis (ITS-rDNA and TEF-1 $\alpha$ ) and their pathogenicity tests under field conditions. Representative isolates tested for pathogenicity proved that, all the tested isolates were virulent and aggressive pathogens. PFSR produces similar symptoms when it was affected by different Fusarium species. Therefore, identification of associated pathogen based on symptomatology is highly difficult. More so, the Fusarium species are cryptic in nature and it is very difficult to distinguish them based on morphology alone.

Identification of Fusarium species is mainly based on morphological characteristics. Some species of Fusarium are known to have overlapping conidial and colony characteristics, hence, molecular identification tools are being employed recently. In the present study, besides ITSrDNA, TEF genes were used for identification of the $F$. verticillioides and to support the morpho-cultural identity of the pathogen. However, there is a conflict on acceptance of $F$. verticillioides with $F$. fujikuroi. In the scientific literature pertaining to maize stalk rot $F$. verticillioides is reported as the causal agent, though it was long back treated systematically as the synonym of $F$. fujikuroi - which is accepted and 


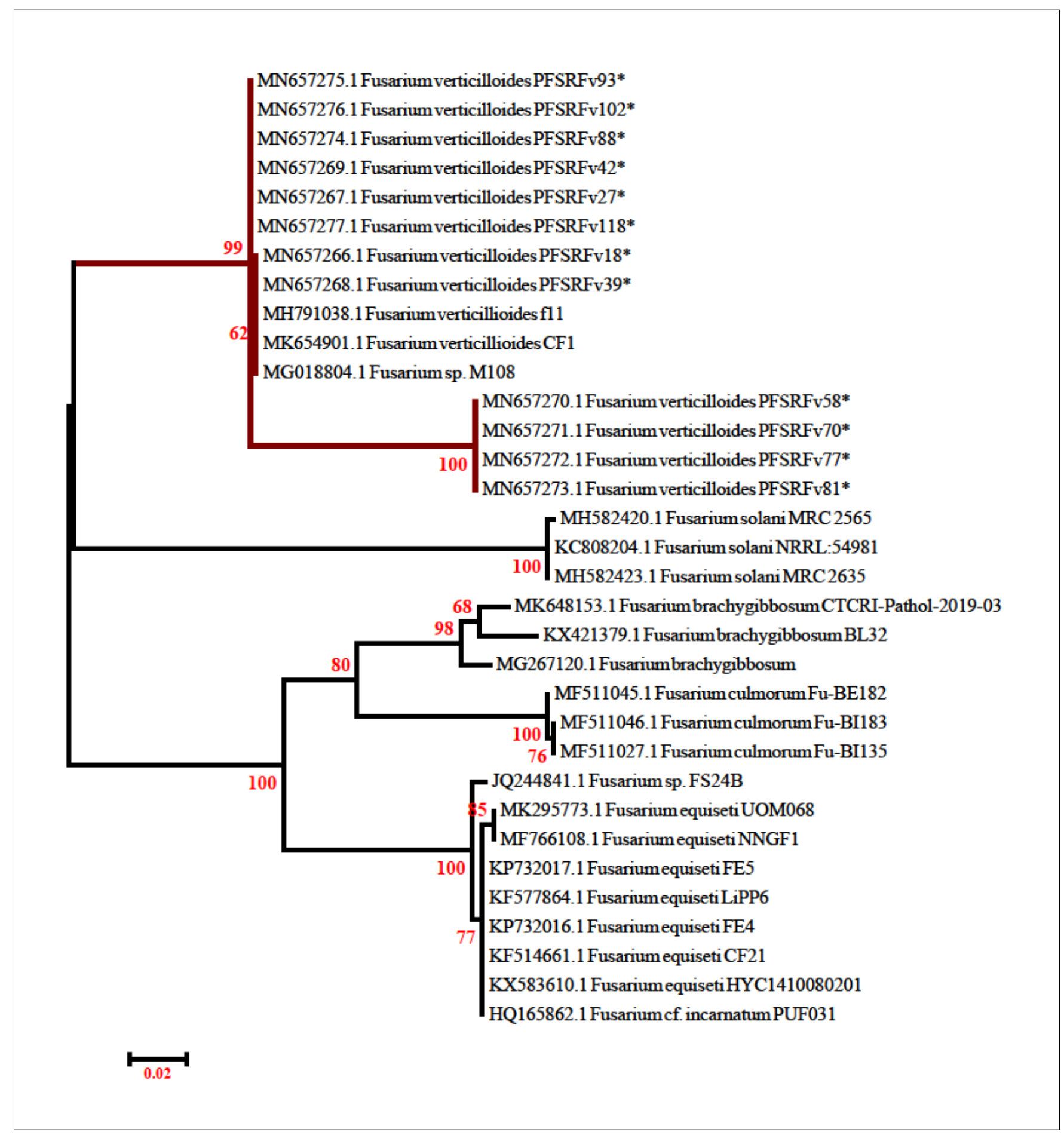

Fig. 8. Phylogenetic tree constructed by Maximum Likelihood method inferred from Translation elongation factor (TEF) sequences showing relationships among isolates of Fusarium verticillioides and related Fusarium species (Substitution nucleotide Tamura-Nei model and boot strap methods with 1000 bootstrap replications).

legitimate name as presented in many curate databases like Index Fungorum and Fusarium ID. However, review of recent papers on stalk rot of maize found that almost all of them reported the associated Fusarium species as $F$. verticillioides and never considered $F$. fujikuroi as an alternate name for $F$. verticillioides. Further, Choi et al. (2018) reported that $F$. verticilloides and $F$. fujikuroi are two different species. Therefore, to clear the perplexity or indistinctness in taxonomic position of $F$. fujikuroi and $F$. verticilloides, further work needs to be conducted with five major loci which may help to resolve the issues.

To our knowledge, this study is the first to report the severe 


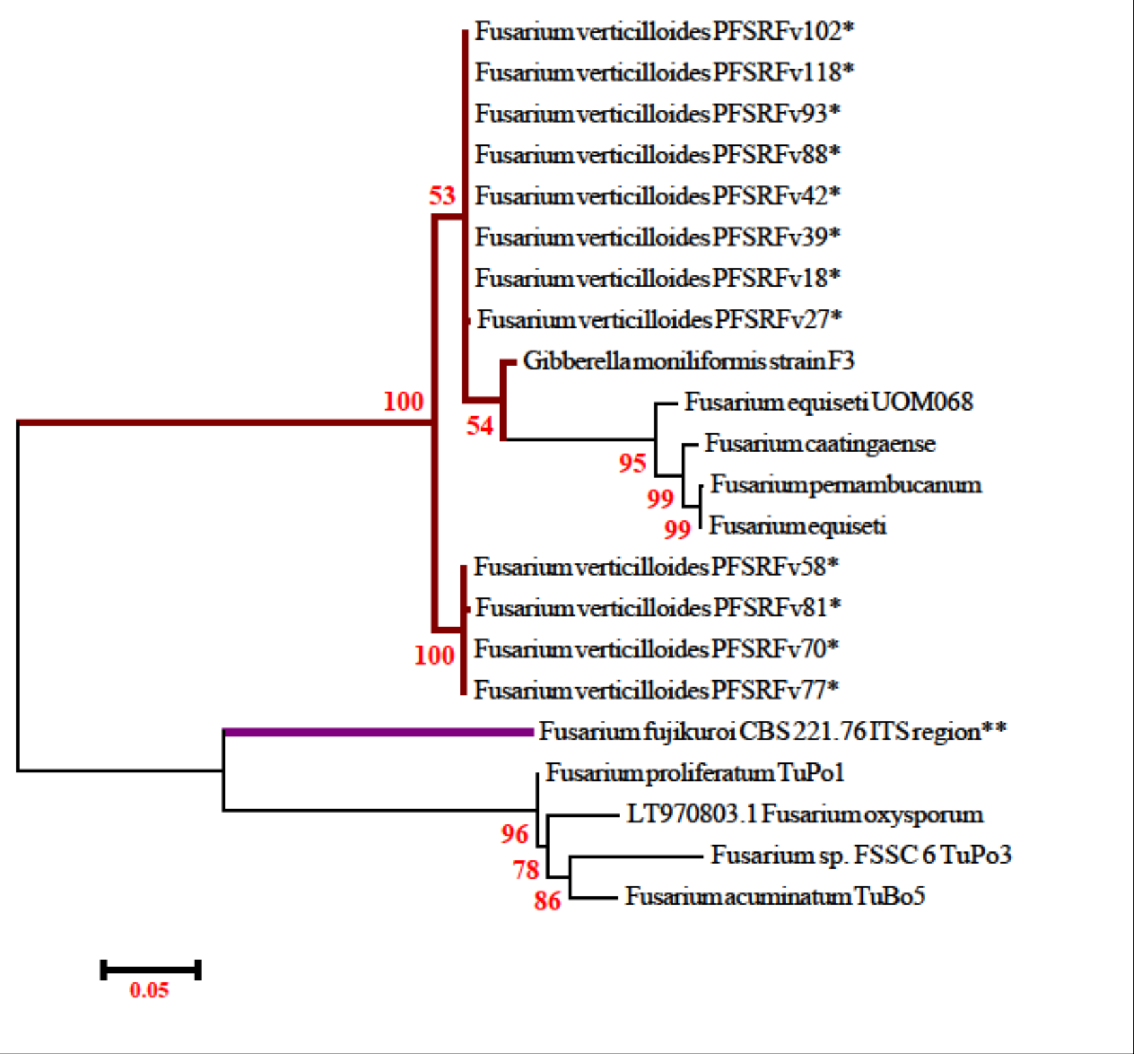

Fig.9. Phylogenetic tree constructed by Maximum Likelihood method inferred from combined ITS-rDNA and Translation elongation factor (TEF) sequences showing relationships among isolates of Fusarium verticillioides and related Fusarium species (Substitution nucleotide Tamura-Nei model and boot strap methods with 1000 bootstrap replications).

occurrence of $F$. verticillioides associated with PFSR of maize in Karnataka and to confirm their identity by morphological and molecular characterization followed by pathogenicity and assessing their virulence under field conditions. The results of the present work provide conclusive evidence for the dominance of $F$. verticillioides as the causal agent of PFSR and on the other hand the work also emphasizes on other potential pathogens affecting the maize growers, if not contained at the earliest. Therefore, effort should be made to manage the fungal diseases with suitable and economical management practices. Further, understanding the variations within Fusarium species complex will provide insights into the ability of this genus to evolve in response to environmental conditions, and to record the different species associated with stalk rot of maize.

\section{ACKNOWLEDGEMENTS}

We would like to thank the Department of Studies in Botany, University of Mysore, for providing all necessary facilities to carry out the experiments. MKS wishes to thank Council of Scientific and Industrial Research (CSIR), New Delhi for awarding CSIR-Research Associate Fellowship. KRS is grateful to Mangalore University and Yenepoya (deemed to be) University for the award of Adjunct Professorship. We thank anonymous reviewers for their critical reading and comments for improving the manuscript. 


\section{REFERENCES}

Afolabi, C.G., Ojiambo, P.S., Ekpo, E.J.A., Menkir, A. and Bandyopadhyay, R. 2008. Novel sources of resistance to Fusarium stalk rot of maize in tropical Africa. Plant Disease 92: 772-780.

Anonymous 2016. Retrieved from the source @ Indiastat.comhttp://www.indiastat.com/agriculture/ 2/foodgrains/17180/maize/17199/stats.aspx (on 04/ 06/2017).

Anonymous 2017.http://agricoop.nic.in/recentinitiatives/ pocket-book-agricultural-statistics-2017, Accessed date: 24 January 2019.

Arya, H.C. and Jain, B.L. 1964. Fusarium seedling blight of maize in Rajasthan. Indian Phytopathology 17: 51-57.

Bacon, C. W. and Nelson, P. E. 1994. Fumonisin production in corn by toxigenic strains of Fusarium moniliforme and Fusarium proliferatum. Journal of Food protection 57: 514-521.

Booth, C. 1971. The genus Fusarium. The Eastern Press, London.

Borah, S.N., Deka, S. and Sarma, H.K. 2016. First Report of Fusarium verticillioides Causing Stalk Rot of Maize in Assam, India. Plant Disease 100 (7): 1501-1501.

Choi, H. W., Hong, S. K., Lee, Y. K., Kim, W. G. and Chun, S., 2018. Taxonomy of Fusarium fujikuroi species complex associated with bakanae on rice in Korea. Australasian Plant Pathology, 47: 23-34. https://doi.org/10.1007/s13313-017-0536-6

Christensen, J.J. and Wilcoxson, R.D. 1966. Stalk rot of Corn. Monograph 3. American Phytopathological Society, USA.

De León, C. and Pandey, S. 1989. Improvement of Resistance to Ear and Stalk Rots and Agronomic Traits in Tropical Maize Gene Pools. Crop Science 29: 12-17.

Deepa, N., Nagaraja, H. and Sreenivasa, M.Y. 2016a. Prevalence of fumonisin producing Fusarium verticillioides associated with cereals grown in Karnataka (India). Food Science and Human Wellness 5: 156-162.

Deepa, N., Rakesh, S. and Sreenivasa, M.Y, 2016b. Morphological, pathological and mycotoxicological variations among Fusarium verticillioides isolated from cereals. 3 Biotech. 8(2): 105.

Deepa, N., Rakesh, S. and Sreenivasa, M. Y. 2018. Morphological, pathological and mycotoxicological variations among Fusarium verticillioides isolated from cereals. 3 Biotech. 8 (2):105. Doi:10.1007/ s13205-018-1136-z.

Dorn, B., Forrer, H.R., Schurch, S. and Vogelgsang, S. 2009. Fusarium species complex on maize in Switzerland: occurrence, prevalence, impact and mycotoxin in commercial hybrids under natural infection. European Journal of Plant Pathology 125: 51-61.

Felsenstein, J. 1985. Confidence limits on phylogenies: An approach using the bootstrap. Evolution 39:783-791.

Gai, X., Dong, H., Wang, S., Liu, B., Zhang, Z., Li, X. and Gao, Z. 2018. Infection cycle of maize stalk rot and ear rot caused by Fusarium verticillioides. PLoS ONE 13 (7): e0201588.

Geiser, D.M., Jimenz-Gasco, M.M., Kang, S., Mkalowska, I., Veeraraghavan, N., Ward, T.J., Zhang, N., Kuldau, G.A. and O'Donnell, K. 2004. FUSARIUMIDv.1.0: A DNA sequence database for identifying Fusarium. European Journal of Plant Pathology 110: 473-479.

Gilbertson, R.L., Brown, W.M., Jr. and Ruppel, E.G. 1985. Prevalence and virulence of Fusarium spp. associated with stalk rot of corn in Colorado. Plant Disease 69: 1065-1068.

Jat, A., Sharma, S.S. and Dhakar, H. 2017. Morphological characterization and biochemical defense studies of Fusarium verticillioides (sheldon) causing post flowering stalk rot of specialty corn. International Journal of Chemical Studies 5 (6): 902-905.

Khokhar, M.K., Hooda, K.S., Sharma, S.S. and Singh, V. 2014. Post Flowering Stalk Rot Complex of Maize Present Status and Future Prospects. Maydica 59: 226-242.

Khokhar, M.K., Hooda, K.S., Sharma, S.S., Singh, V. and Saini, A. 2013. Fusarium stalk rot: A major threat to maize production in India. Maize Journal 2: 1-5.

Kling, J. G. and Edmeades, G. 1997. Morphology and growth of maize-Research Guide, No.9 Pp. 3-6.

Kommedahal, T., Windels, C.E. and Stucker, R.E. 1972. Occurrence of Fusarium species in root and stalks symptoms in corn plants during the growing season. Phytopathology 69:961-966.

Kumar, S., Stecher, G. and Tamura, K. 2016. Molecular Evolutionary Genetics Analysis version 7.0 for bigger datasets. Molecular Biology and Evolution 33: $1870-1874$.

Leslie, J.F. and Summerell, B.A. 2006. The Fusarium laboratory manual. Blackwell Publishing Company, Ames, USA.

Li, P., Shi, Y., Guo, M., Xie, X., Chai, A. and Li, B. 2017. Fusarium wilt of cauliflower caused by Fusarium equiseti in China. Canadian Journal of Plant Pathology 39 (1): 77-82.

Li, P.P., Cao, Z.Y., Wang, K., Zhai, H., Jia, H., Liu, N., Li, S.H., Hao, Z.M., Gu, S.Q. and Dong, J.G. 2014. First report of Fusarium equiseti causing a sheath rot of corn in China. Plant Disease 98: 998.

Mahadevakumar, S., Amruthavalli, C., Sridhar, K.R., Janardhana, G.R., 2017. Prevalence, incidence and molecular characterization of Phomopsis vexans (Diaporthe vexans) causing leaf blight and fruit rot disease of brinjal in Karnataka (India). Plant Pathology and Quarantine 7: 29-46.

Mahadevakumar, S., Chandana, C., Deepika, Y.S., Sumashri, 
K.S., Vandana Yadav and Janardhana, G.R. 2018. Pathological studies on southern blight disease of China aster (Callistephus chinensis) caused by Sclerotium rolfsii. European Journal of Plant Pathology 151 (4):1081-1087.

Mahadevakumar, S., Chandana, C. and Janardhana, G.R. 2019. Association of Colletotrichum truncatum with anthracnose disease of Tuberose (Polianthes tuberosa) in India. Crop Protection 118: 1-5.

Marasas, W. 2001. Discovery and occurrence of fumonisins: A historical perspective. Environmental and Health perspective 109: 239-243.

Marasas, W.F.O., Nelson, P.E. and Toussoun, T.A. 1984. Toxigenic Fusarium species: Identity and mycotoxicology. The Pennsylvania State University Press, University Park, USA.

Nagaraja, H., Chennappa, G., Rao, K.P.C., Prasad, G.M. and Sreenivasa, M.Y. 2016. Diversity of toxic and phytopathogenic Fusarium species occurring on cereals grown in Karnataka state, India. 3 Biotech. 6: 57 .

Nayaka, S.C., Shankar, A.C.G.U., Niranjana, S.R. and Prakash, H.S. 2008. Molecular detection and characterization of Fusarium verticillioides in maize (Zea mays L.) grown in southern India. Annals of Microbiology 58(3): 359-367.

Nur Ain Izzati, M.Z., Azmi, A.R., Siti Nordahliawate, M.S. and Norazlina, J. 2011. Contribution to knowledge of diversity of Fusarium associated with maize in Malaysia. Plant Protection Science 47: 20-24

O'Donnell, K., Kistler, H.C., Cigelink, E. and Ploetz, R.C. 1998. Multiple evolutionary origins of the fungus causing Panama disease of banana: Concordant evidence from nuclear and mitochondrial gene genealogies. Proceedings of National Academy Science 95: 2044-2049.

Orsi, R.B., Correa, B., Possi, C.R., Schammass, E.A., Nogueira, J.R., Dias, S.M.C. and Malozzi, M.A.B., 2000. Microflora and occurrence of fumonisin in freshly harvested and stored hybrid maize. Journal of Stored Product Research 36: 75-87.

Pammel, L.H. 1914. Serious root and stalk diseases of corn. IOWA Agriculturist 15: 156-158.

Rakesh, B., Gangappa, E., Gandhi, S., Ramesh, S. and Nagaraju, N. 2016. Identification of Maize (Zea mays L.) inbred lines resistant to late wilt disease caused by Harpophora maydis. Mysore Journal of Agricultural Science 50 (2): 366-368.

Rheeder, J. P., Marasas, W. F. O. and Vismer, H. F. 2002. Production of Fumonisin analogs by Fusarium species. Applied and Environmental Microbiology 68(5): 2101-2105.

Saitou, N. and Nei, M. 1987. The neighbor-jining method: A new method for reconstructing phylogenetic trees. Molecular Biology and Evolution 4: 406-425.
Shan, L.Y., Cui, W.Y., Zhang, D.D., Zhang, J., Ma, N.N., Bao, Y.M., Dai, X.F. and Guo, W., 2017. First Report of Fusarium brachygibbosum causing maize stalk rot in China. Plant Disease 101 (5): 837.

Shekhar, M. and Kumar, S. 2012. Inoculation methods and disease rating scales for maize diseases. Directorate of Maize research (ICAR), New Delhi. Available online@http://krishi.icar.gov.in:8080/jspui/ bitstream/123456789/2100/1/Inoculation\%20Meth ods $\% 20$ and $\% 20$ Disease $\% 20$ Rating $\% 20$ Scales $\% 20$ for\%20Maize\%20Diseases.pdf (Accessed on 18 May 2015).

Shim, W. B., Flaherty, J. E. and Woloshuk, C. P. 2003. Comparison of fumonisin B1 biosynthesis in maize germ and degermed kernels by Fusarium verticillioides. Journal of Food Protection, 66: 2116-2122.

Swamy, D. S., Mahadevakumar, S., Amruthesh, K. N., Swapnil, R. and Lakshmidevi, N., 2019. Survey and surveillance for disease prevalence and incidence of stalk rot of maize in Karnataka. International Journal of Agricultural Sciences 11 (12): 8633-8637.

Swamy, D. S., Mahadevakumar, S., Hemareddy, H. B., Amruthesh K. N., Mamatha, S., Sridhar G. Kunjeti, Swapnil, R., Vasantha Kumar, T. and Lakshmidevi, N., 2020. First report of Fusarium equiseti associated with post flowering stalk rot of Maize (Zea mays L.) in India. Crop Protection 129 (105035): 1-7 (Published online).

Tamura, K., Neim, M. and Kumar, S. 2004. Prospects for inferring very large phylogenies by using the neighbor-joining method. Proceedings of National Academy Science, USA 101: 11030-11035.

Tamura, K., Stecher, G., Peterson, D., Filipski, A. and Kumar, S.2013. Phylogenetic and molecular evolutionary analyses were conducted using MEGA version 6. Molecular Biology and Evolution 30: 2725-2729.

Vasanthkumar, T. and Shetty, H.S. 1983. Seed borne nature and transmission of Botryodiplodia theobromae in maize (Zea mays L.). Seed Science and Technology 11: 781-789.

White, D.G., 1999. Fungal stalk rots. In: Compendium of Corn Diseases (Ed.: White, D.G.). American Phytopathological Society Press, St. Paul,MN. pp. 38-44.

White, T., Bruns, T., Lee, S. and Taylor, J. 1990. Amplification and direct sequencing of fungal ribosomal RNA genes for phylogenetics. In: $P C R$ Protocols, a Guide to Methods and Applications. (Eds.: Innis, M.A., Gelf and, D.H., Sninsky, J.J. and White, T.J.). Academic Press, New York, USA, pp. 315-322.

Zhang, Y.P., Uyemoto and Kirkpatrick, B.C. 1998. A smallscale procedure for extracting nucleic acids from woody plants infected with various phytopathogens for PCR assay. Journal of Virological Methods 71: 45-50. 